\title{
INFLUENCE OF AUXILIARY EXHAUST VALVE WITH VARIABLE TIMING ON SPARK IGNITION ENGINE PERFORMANCE
}

\author{
Ahmed, S.A. , Ibrahim, A. M..", Wassef, F. M.. and \\ Selim, $\boldsymbol{H}$. \\ * : lecture assistant **: Professor \\ Mechanical Engineering Department, Faculty of Engineering, Assiut \\ University, 71516 Assiut
}

(Received November 22, 2009 Accepted December 30, 2009).

New Variable valve timing strategy based on using auxiliary valve having variable timing (VVT) is used in this study. The valve is driven by a new variable valve timing mechanism constructed for this purpose. The auxiliary valve acts as an exhaust valve and the experiments and simulation model are carried out at different loads. The results show that engine performance is improved at full load and worsens at part loads. The study proves that using an auxiliary exhaust valve having variable timing is not recommended in engines applications.

\begin{tabular}{|llcll|}
\hline \multicolumn{4}{c|}{ NOMENCLATURE } \\
$A$ & Area $\left(\mathrm{m}^{2}\right)$ & $x$ & Mass fraction, position \\
$c_{p}, c_{v}$ & Specific heats under constant & & co-ordinate \\
& pressure, volume $(\mathrm{J} / \mathrm{kg} . \mathrm{K})$ & & Greek Symbols \\
$D$ & Local mean diameter through & $\theta$ & Crank position angle (degree) \\
& intake and exhaust systems $(\mathrm{m})$ & $\Delta \theta_{c}$ & Combustion duration (degree) \\
$e$ & Specific internal energy $(\mathrm{kJ} / \mathrm{kg})$ & $\sigma$ & Boltzman constant \\
$f$ & Darcy friction factor & $\rho$ & Density $\left(\mathrm{kg} / \mathrm{m}^{3}\right)$ \\
$h$ & Specific enthalpy $(\mathrm{kJ} / \mathrm{kg})$ & $\phi$ & Equivalence ratio \\
$k$ & Specific heats ratio & $B$ & Burn \\
$k^{\prime}$ & Thermal conductivity $(\mathrm{W} / \mathrm{m} . \mathrm{K})$ & $u$ & Unburn \\
$m$ & Mass (kg) & $w$ & wall \\
$N$ & Engine speed (rpm) & & Superscripts \\
$Q, \dot{q}_{w}$ & Heat transfer $(\mathrm{kJ})$, heat flux & & Derivative with time $(\mathrm{d} / \mathrm{dt})$ \\
& through cylinder walls $\left(\mathrm{j} / \mathrm{m}^{2}\right)$ & - & Molar quantity \\
$u$ & Local gas velocity through & & \\
& intake and exhaust pipes $(\mathrm{m} / \mathrm{s})$ & &
\end{tabular}

\section{INTRODUCTION}

Recently, variable valve timing engines (VVT) have attracted a lot of attention because of their ability to control valve events independent of crankshaft rotation, allowing for reduced pumping losses and increased brake thermal efficiency over a wider range than conventional spark-ignition engines. Variable valve timing also allows control of internal exhaust gas recirculation (by control of the valve overlap), allowing for control 
of engine emissions. There are four VVT strategies [1,2,3]: (1) Phasing only the intake valve. (2) Phasing only the exhaust valve. (3) Phasing the exhaust and the intake valves equally. (4) Phasing the exhaust and the intake valves independently. In this study a new strategy is achieved by using VVT mechanism with an auxiliary valve, while both main intake and exhaust valves have fixed timing. The auxiliary valve can be used as intake or exhaust valve. In this study, it will be used as exhaust valve to study the influence of application of the new strategy on the engine performance. A new VVT mechanism, having the ability of changing valve duration and opening angle with respect to the crankshaft, is designed for controlling the auxiliary valve.

\section{THEORETICAL MODEL}

\subsection{Assumptions}

The main assumptions considered in this simulation model are: (1) Cylinder content is homogenous mixture through intake, compression, expansion and exhaust processes. (2) Two zones combustion model is assumed, each zone has a local temperature and thermodynamic properties, while pressure is uniform through the two zones. (3) Flame propagation is a spherical surface; its center is the spark plug. (4) Temperature of cylinder head, cylinder walls, piston crown, intake manifold, and exhaust manifold are constant. (5) The exhaust and intake valves are considered as converging nozzle through both forward and reverse flow. (7) Carburetor is modeled as venturi followed by an orifice representing the throttle valve.

\subsection{Mathematical and Thermodynamic Submodels}

Combustion Products Model For Temperature less than $1700 \mathrm{~K}$, the general combustion equation for hydrocarbon fuel with air may be written as [4]:

$$
\mathrm{C}_{w} \mathrm{H}_{x} \mathrm{O}_{y} \mathrm{~N}_{z} \longrightarrow n_{1} \mathrm{CO}_{2}+n_{2} \mathrm{H}_{2} \mathrm{O}+n_{3} \mathrm{CO}+n_{4} \mathrm{H}_{2}+n_{5} \mathrm{O}_{2}+n_{6} \mathrm{~N}_{2}
$$

Where $\mathrm{CO}$ moles are calculated using the water gas reaction for rich mixture.

For Temperature higher than $1700 \mathrm{~K}$, eleven products are assumed [4,5]. The reaction equation is written as:

$$
\begin{aligned}
\mathrm{C}_{w} \mathrm{H}_{x} \mathrm{O}_{y} \mathrm{~N}_{z} \longrightarrow & n_{1} \mathrm{CO}_{2}+n_{2} \mathrm{CO}+n_{3} \mathrm{O}_{2}+n_{4} \mathrm{O}+n_{5} \mathrm{~N}_{2}+n_{6} \mathrm{NO} \\
& +n_{7} \mathrm{~N}+n_{8} \mathrm{H}_{2}+n_{9} \mathrm{H}+n_{10} \mathrm{OH}+n_{11} \mathrm{H}_{2} \mathrm{O}
\end{aligned}
$$

Where $n_{1}, \ldots, n_{11}$ are calculated from mass balance equations of $C, H, O$ and $N$ and seven dissociation reactions as given by Campbell [ 5] .

\section{Thermodynamic Properties of Cylinder Content Model:}

The thermodynamic properties of each species in the gas mixture inside the cylinder are calculated by using of the JANAF tables. According to this program, the thermodynamic properties of the combustion species as functions of temperature are given in polynomial form [4].

$$
\bar{c}_{p_{i}} / \bar{R}=a_{i 1}+a_{i 2} T+a_{i 3} T^{2}+a_{i 4} T^{3}+a_{i 5} T^{4}
$$




$$
\bar{h}_{i} /(\bar{R} T)=a_{i 1}+\frac{a_{i 2}}{2} T+\frac{a_{i 3}}{3} T^{2}+\frac{a_{i 4}}{4} T^{3}+\frac{a_{i 5}}{5} T^{4}+\frac{a_{i 6}}{T}
$$

Values of the polynomial coefficients for each species are given in [4]. Fuel vapor thermodynamic properties are calculated by the following equations [4]:

$$
\begin{aligned}
& \bar{c}_{P f}=C_{1}+C_{2} t+C_{3} t^{2}+C_{4} t^{3}+C_{5} / t^{2} \\
& \bar{h}_{f}=C_{1} t+C_{2} \frac{t^{2}}{2}+C_{3} \frac{t^{3}}{3}+C_{4} \frac{t^{4}}{4}-\frac{C_{5}}{t}+C_{6}+C_{7}
\end{aligned}
$$

Where: $t=T / 1000, C_{1}, C_{2}, \ldots, C 7$ are constants and their values are given in [4].

Engine Friction The mechanical losses due to friction between engine parts are expressed in terms of friction mean effective pressure (fmep). These losses are calculated according to Bishop model [6] as follows.

Piston losses:

$$
(\text { fmep })_{1}=6.2 n_{r}+\left\{0.606 r_{c}+1.254 r_{c}^{1.37-0.02388_{P}}\right\}+9.3 S_{P}^{1.03}
$$

Blowby losses:

$$
(\text { fmep })_{2}=11.86 r_{c}^{0.4}-\left(3.38+0.103 r_{c}\right)+6.89\left(\frac{N}{1000}\right)^{1.185}
$$

Exhaust and inlet system throttling losses:

$$
(\text { fmep })_{3}=p_{\text {in }}+p_{\text {em }} / 2.75
$$

Crankcase mechanical losses:

$$
(\text { fmep })_{4}=12.122\left(\frac{d N}{1000 l}\right)+0.07\left\{30-\frac{4 N}{1000}\right\}\left(\frac{n_{i v} D_{i v}{ }^{1.75}}{d^{2} l}\right)+2.688\left(\frac{N}{1000}\right)^{1.5}
$$

Valve pumping losses:

$$
(\text { fmep })_{5}=8.96\left(\frac{N}{1000}\right)^{1.7}\left(\frac{2.98 V_{d}}{n_{i v} n_{c} D_{i v}^{2}}\right)^{1.298}
$$

Cylinder Heat Transfer: Instantaneous heat transfer rate between the working fluid and the surrounding surfaces of the cylinder is calculated by using Annand equation [7].

$$
q_{w}=\hat{a}\left(k^{\prime} / d\right)(\operatorname{Re})^{\hat{b}}\left(T-T_{w}\right)+\hat{c} \sigma\left(T^{4}-T_{w}^{4}\right)
$$

Where: $\hat{a}=0.5, \hat{b}=0.7, \hat{c}=0$ during compression and $\hat{c}=0.4$ during the rest of cycle,

Combustion Process: Burned mass fraction of fuel is calculated by using Wiebe function $[4,8]$ :

$$
x_{b}=1-\exp \left\{-a_{b}\left(\left(\theta-\theta_{o}\right) / \Delta \theta_{c}\right)^{b_{b}+1}\right\}
$$

Where $\theta_{o}$ is the crank angle at which combustion starts, $\Delta \theta_{c}$ is the combustion duration in degrees CA, $a_{b}=2$ and $b_{b}=5$. Cylinder volume is divided into two zones, burned zone has a volume $V_{b}$ and unburned zone has a volume $V_{u}$. These volumes are calculated by Annand mathematical model [9] as shown in Fig.1. 


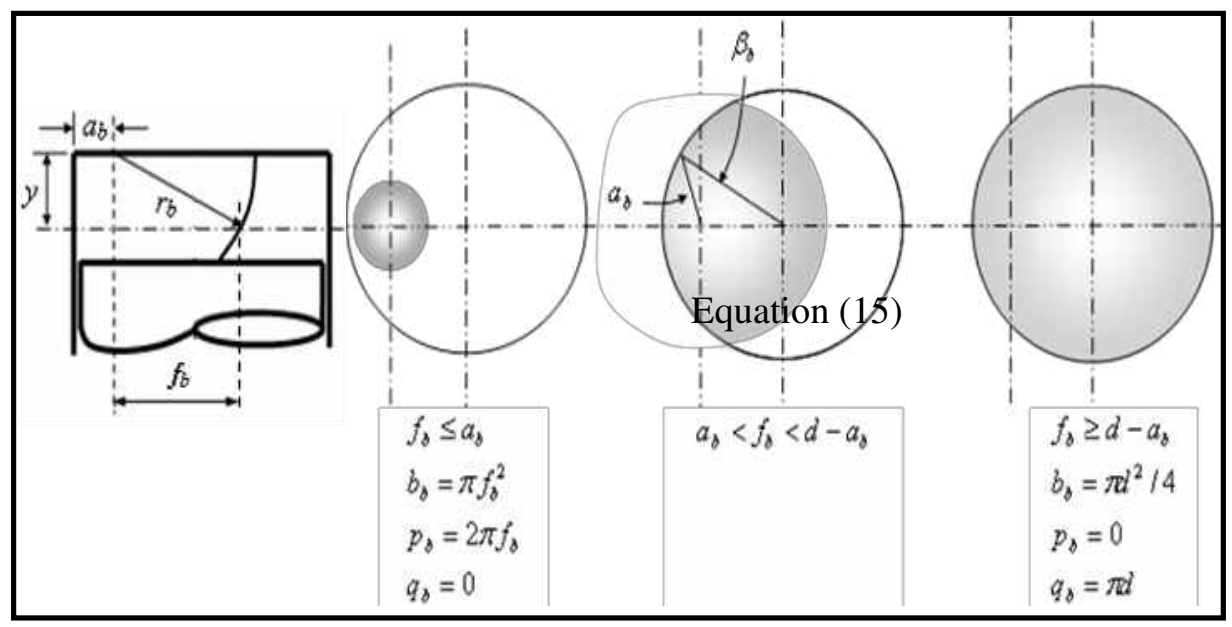

Fig. 1 Flame propagation through combustion chamber

Burned volume $V_{b}$, area of flame front $S_{b}$ and chamber area that is in contact with burned zone $A_{b}$ are calculated by the following equations:

$$
V_{b}=\int_{0}^{x} b_{b} d y \quad, \quad S_{b}=\int_{0}^{x}\left(r_{b} p_{b} / f_{b}\right) d y \quad \text { and } \quad A_{b}=\int_{0}^{x} q_{b} d y
$$

Where $f_{b}$ is the radius of intersection of flame front with plane $\mathrm{y}, p_{b}$ is the perimeter of flame front measured in plane $\mathrm{y}$, and $q_{b}$ is the perimeter of intersection measured in plane y.

$$
\begin{aligned}
& \cos \alpha=\left[\frac{a_{b}}{d}-\left(\frac{a_{b}}{d}\right)^{2}-\left(\frac{f_{b}}{d}\right)^{2}\right] /\left[1-2 a_{b}\left(\frac{f_{b}}{d}\right)\right] \\
& \cos \beta=1+\left[\left(\frac{a_{b}}{d}\right)^{2}-\left(\frac{f_{b}}{d}\right)^{2}\right] /\left(0.5-\frac{a_{b}}{d}\right) \\
& b_{b}=[\pi-\alpha+0.5 \times \sin (2 \alpha)] f_{b}^{2}+\left[2 \beta-\sin (2 \beta) d^{2} / 8\right] \\
& r_{b} p_{b} / f_{b}=2(\pi-d) r \\
& q=d \times \beta
\end{aligned}
$$

Pressure and Temperature Relationships: Applying the first law of thermodynamic for an open system on the engine cycle yields $[10,11]$.

$$
\begin{aligned}
& T=\frac{1}{m C_{v}}\left\{Q-p V+\sum\left(m_{i n} h_{i n}-m_{e x} h_{e x}\right)-e m-m \sum_{i} e_{i} x_{i}\right\} \\
& p=\frac{\rho}{\partial \rho / \partial p}\left\{\frac{m}{m}+\sum_{i} \frac{R_{i} x_{i}}{R}-\frac{V}{V}-\frac{\partial \rho / \partial T}{\rho} T\right\}
\end{aligned}
$$

Where: $i$ denotes the number of species in the working medium inside the cylinder. These equations are used in intake, compression, expansion and exhaust processes. In combustion process the cylinder is assumed to be divided into two zones, burned zone and unburned zone governed by the following equations [12,13]: 


$$
\begin{aligned}
& T_{u}=\frac{1}{m_{u} c_{p u}}\left(V_{u} p+Q_{u}\right) \\
& T_{b}=\frac{p}{m_{b} R_{b}}\left\{V-\left(\frac{R_{b} T_{b}}{p}-\frac{R_{u} T_{u}}{p}\right) m_{b}+\left(\frac{V}{p}-\frac{R_{u} V_{u}}{p c_{p u}}\right) p-\frac{R_{u}}{p c_{p_{u}}} Q_{u}\right\} \\
& p=-\frac{1}{X^{o}}\left\{\left(1+\frac{c_{v b}}{R_{b}}\right) p V+\left(\left(U_{b}-U_{u}\right)-c_{v b}\left(T_{b}-\frac{R_{u}}{R_{b}} T_{u}\right)\right) m_{b}+Y^{o} Q_{u}-Q\right\} \\
& \text { Where: } \quad X^{o}=Y^{o} V_{u}+\frac{c_{v b}}{R_{b}} V \quad \text { and } \quad Y^{o}=\frac{c_{v u}}{c_{p b}}-\frac{c_{v b} R_{u}}{c_{p_{u}} R_{b}}
\end{aligned}
$$

NO $\mathbf{O}_{x}$ Formation Mechanism: The extended Zeldovich mechanism mentioned in $[4,8,14]$ is widely used. The mechanism consists of three reactions:

$$
\begin{aligned}
& \mathrm{O}+\mathrm{N}_{2} \longleftrightarrow \mathrm{NO}+\mathrm{N} \\
& \mathrm{N}+\mathrm{O}_{2} \longleftrightarrow \mathrm{NO}+\mathrm{O} \\
& \mathrm{N}+\mathrm{OH} \longleftrightarrow \mathrm{NO}+\mathrm{H}
\end{aligned}
$$

These equations are solved assuming steady state formation of $N$ and equilibrium values at the local pressure and temperature for $\mathrm{O}, \mathrm{O}_{2}, \mathrm{OH}, \mathrm{H}$ and $\mathrm{N}_{2}$. The resulting $N O$ formation rate is:

$$
\frac{d}{d t}[N O]=2 k_{1 f}[O]_{e}\left[N_{2}\right]_{e}\left\{\frac{1-[N O]^{2} /\left(K_{12}\left[O_{2}\right]_{e}\left[N_{2}\right]_{e}\right)}{1+k_{1 b}[N O] /\left(k_{2 f}\left[O_{2}\right]_{e}+k_{3 f}[O H]_{e}\right)}\right\}
$$

Where: $K_{l 2}=\left(k_{1 f} f k_{l b}\right) /\left(k_{2 f} / k_{2 b}\right)$, subscripts 1,2 and 3 refer to the three reactions in equation (22) of the mechanism respectively, subscript $e$ refers to equilibrium, [4] denotes concentration in mole $/ \mathrm{cm}^{3}$. The rate constants are mentioned in [4].

CO Formation Mechanism: $C O$ formation rate is calculated by the following equation which is suggested by Annand [15]:

$$
\left.\frac{d}{d t}[C O]=-10^{9} \exp (-4500 / \bar{R} T)\{C \mathrm{CO} \coprod \mathrm{OH}]-\left[\mathrm{CO}_{2}\right][\mathrm{H}] / 10^{(-1.965+4590 / T)}\right\}
$$

HC Emission Mechanism Unburned $H C$ occurs due to flame quenching at cylinder walls, unburned mixture in cylinder craves, absorbed fuel by the oil layer and poor combustion quality. HC oxidation rate are calculated according to Lavoie model [16].

$$
\frac{d}{d t}[H C]=C_{R} A_{R}\left[H C \rrbracket O_{2}\right] \exp (-18735 / T)
$$

Where: $C_{R}=2.0$ and $A_{R}=6.7 * 10^{15} \mathrm{~cm}^{3} /$ mole.s

Flow rate Through Valves: Continuity, momentum and energy equations besides ideal gas and wave action equations are applied to the forward and reverse flow through valves [17]. 
Intake and Exhaust Systems: Flow through both intake, exhaust pipes and carburetor is assumed to be compressible one-dimensional, unsteady flow with friction, heat transfer and gradual area changes. The governing equations are:

$$
\begin{array}{ll}
\text { 1-Continuity Equation: } & \frac{\partial \rho}{\partial t}+\rho \frac{\partial u}{\partial x}+u \frac{\partial \rho}{\partial x}+\rho \frac{u}{A} \frac{d A}{d x}=0 \\
\text { 2-Momentum Equation: } & \frac{\partial u}{\partial t}+u \frac{\partial u}{\partial x}+\frac{1}{\rho} \frac{\partial p}{\partial x}+\frac{f}{D} \frac{u^{2}}{2} \frac{u}{|u|}=0
\end{array}
$$

3- Energy Equation:

$$
\frac{\partial p}{\partial t}+u \frac{\partial p}{\partial x}-a^{2} \frac{\partial \rho}{\partial t}-a^{2} u \frac{\partial \rho}{\partial x}-(k-1) \rho\left\{q+u \frac{f}{D} \frac{u^{2}}{2} \frac{u}{|u|}\right\}=0
$$

Method of characteristics is used for solving the unsteady flow in intake and exhaust system ducts $[8,19]$, by replacing the hyperbolic partial differential equations to total differential equations along certain characteristic lines.

Carburetor throttle valve area is simulated as an orifice. Its value is calculated according to the following equation [4]:

$$
\begin{aligned}
A=\frac{\pi D^{2}}{4}\left\{\left(1-\frac{\cos \psi}{\cos \psi_{o}}\right)+\frac{2}{\pi}\left[\frac{a}{\cos \psi}\left(\cos ^{2} \psi-a^{2} \cos ^{2} \psi_{o}\right)^{\frac{1}{2}}\right.\right. \\
\left.\left.-\frac{\cos \psi}{\cos \psi_{o}} \sin ^{-1}\left(\frac{a \cos \psi_{o}}{\cos \psi}\right)-a\left(1-a^{2}\right)^{\frac{1}{2}}+\sin ^{-1} a\right]\right\}
\end{aligned}
$$

Where: $\psi_{o}, \psi$ are the initial and operated inclination angles of the throttle valve.

\section{EXPERIMENTAL INVESTIGATION}

The experimental work is carried out on a single cylinder, water cooled four stroke spark ignition engine. The engine specifications are illustrated in table 1 . The auxiliary valve durations produced by the VVT mechanism are: 196, 204, 212, 220, 228 and 236 ${ }^{\circ} \mathrm{CA}$. Experiments are carried out for five closing angles for each duration, $20{ }^{\circ} \mathrm{CA}$ BTDC, TDC, $20{ }^{\circ} \mathrm{CA}$ ATDC, $40{ }^{\circ} \mathrm{CA}$ ATDC and $50{ }^{\circ} \mathrm{CA}$ ATDC. These valve closing angles will be denoted in the following figures as $-20^{\circ}, 0^{\circ}, 20^{\circ}, 40^{\circ}$ and $50^{\circ} \mathrm{CA}$ respectively. Figure 2 shows the VVT mechanism that controlled the auxiliary valve timing. The additional camshaft (1) leads multi-face follower (2) which moves the valve. Each face of the follower achieves valve opening duration different from the others. Additional mechanism, consists of two sliding pulleys (5) and (6), that control the valve opening angle. The valve lift profile is measured by LVDT. The LVDT is connected to an electronic circuit which is designed for magnifying its signals. The signals are displayed on a storage oscilloscope connected to PC. Both mass flow rates of air and exhaust gases through the auxiliary valve are measured by orifice meters connected to air boxes which designed according to [20] and modified according to [21,22]. Mass flow rate of fuel is calculated by determining the fuel consumed volume in 400 seconds. Brae power is measured by dynamometer. 
Table 1. Engine specifications

\begin{tabular}{|l|l|c|}
\hline $1-$ & Cylinder bore ,stroke & $65,100 \mathrm{~mm}$ \\
\hline $2-$ & Compression ratio & 6.6 \\
\hline $3-$ & Start of ignition & $26 \mathrm{deg}$. BTDC \\
\hline $4-$ & Main intake valve opening angle & $13 \mathrm{deg}$. BTDC \\
\hline $5-$ & Main intake valve closing angle & $45 \mathrm{deg}$. ABDC \\
\hline $6-$ & Main exhaust valve opening angle & $45 \mathrm{deg}$. BBDC \\
\hline $7-$ & Main exhaust valve closing angle & $17 \mathrm{deg}$. ATDC \\
\hline $8-$ & Intake and exhaust valves head diameter & $26.5 \mathrm{~mm}$ \\
\hline $9-$ & Intake and exhaust valves maximum lift & $5 \mathrm{~mm}$ \\
\hline $10-$ & Auxiliary valve maximum lift & $3.2 \mathrm{~mm}$ \\
\hline $11-$ & Auxiliary valve head diameter & $20 \mathrm{~mm}$ \\
\hline $12-$ & Engine speed & $1200 \mathrm{rpm}$ \\
\hline
\end{tabular}

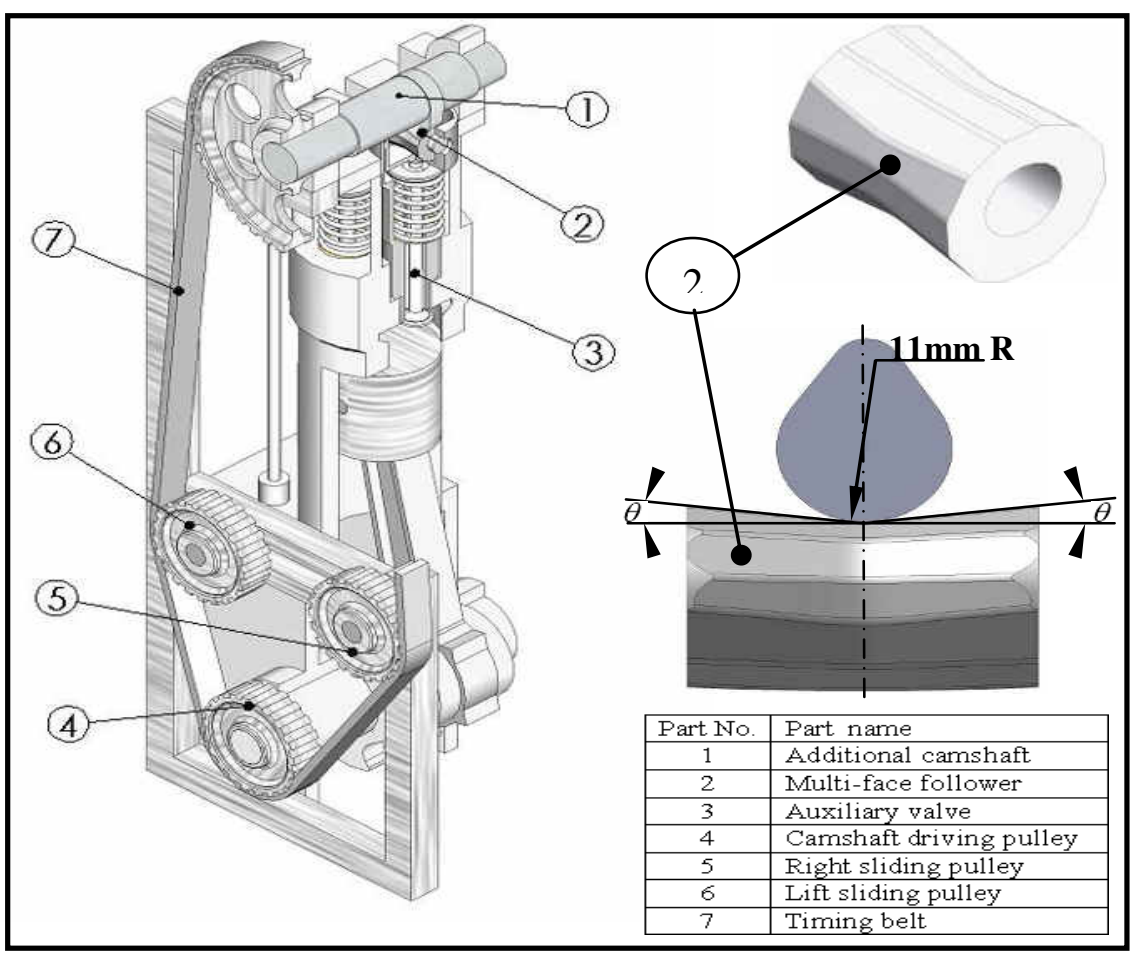

Fig. 2 The auxiliary valve and its driving mechanism assembly 


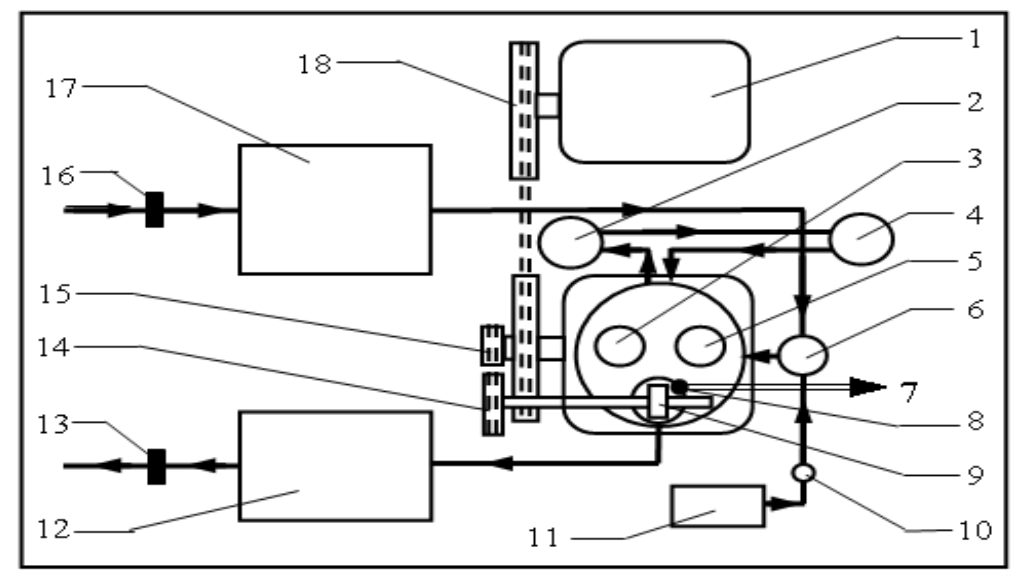

Fig. 3 Schematic diagram of the engine with the associated measuring equipments

Figure 3 shows the schematic diagram of the engine with the associated measuring equipments.

1-Dynamometer 2- Condenser 3- Exhaust valve 4- Water pump 5- Main intake valve 6- Main carburetor 7- LVDT terminals to electric circuit 8- LVDT 9- Auxiliary valve camshaft 10- Main fuel tube 11-Main fuel tank 12- Exhaust surge tank 13- Exhaust orifice meter 14- Auxiliary camshaft driven gear 15- Auxiliary camshaft driving gear 16- Intake orifice meter 17- Intake air box 18- V-belt drive

\section{VALIDATION OF THE MODEL}

The validity of the present simulation model was evaluated by comparing its results with some published experimental work. Figures 4 to 7 illustrate the agreement between experimental and simulation outputs.

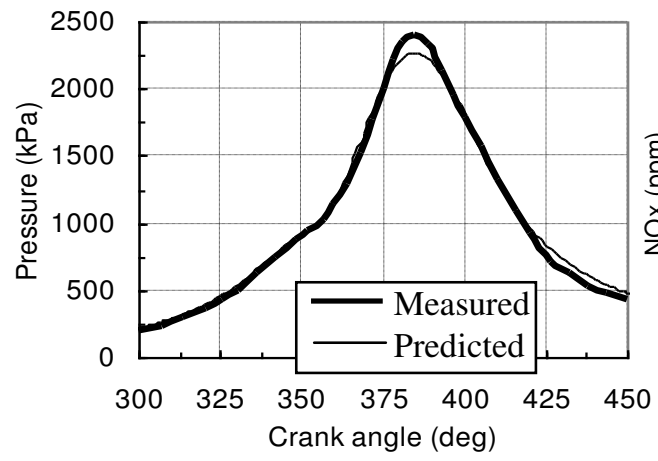

Fig. 4 Comparison between predicted and measured pressure-crank angle diagram by Ref. [23]

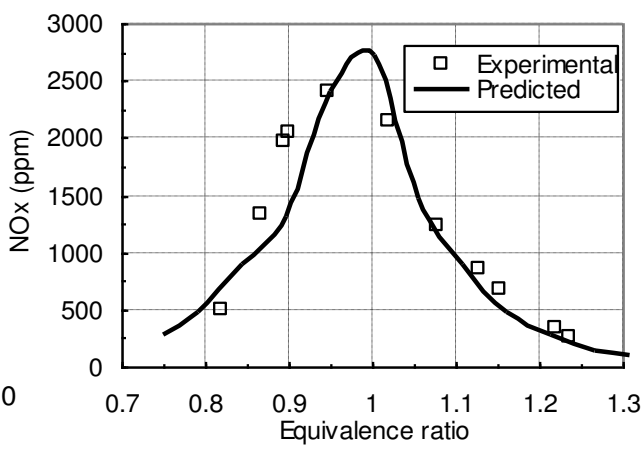

Fig. 5 Comparison between predicted and measured $\mathrm{NO}_{\mathrm{x}}$ concentration by Ref. [24] 


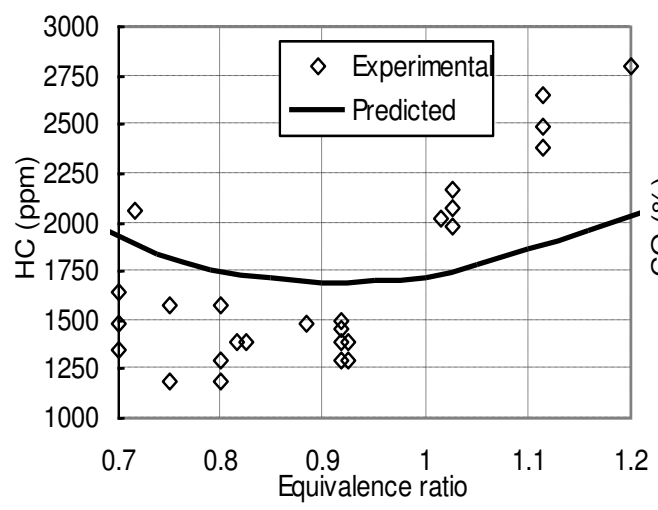

Fig. 6 Comparison between predicted and measured HC concentration by Ref. [16]

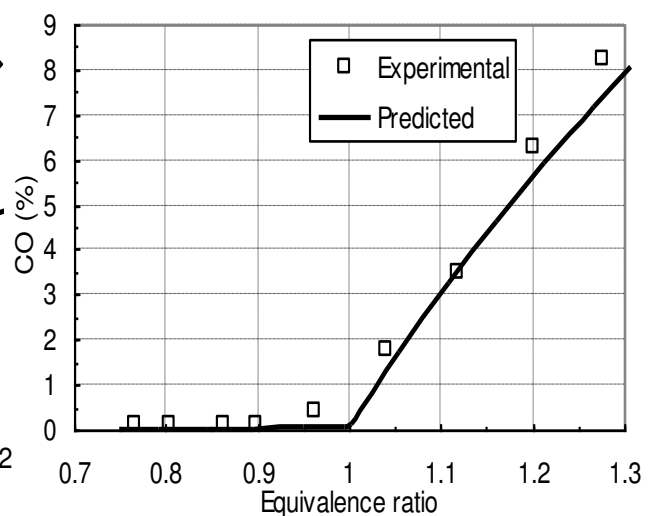

Fig. 7 Comparison between predicted and measured CO concentration by Ref. [23]

\section{ORIGINAL ENGINE PERFORMANCE}

We mean by "original engine" the engine without the auxiliary valve as its outputs will be taken as a reference values for comparison purpose with the VVT engine. Experiments are carried out on the engine at different loads. The loads under consideration are: Full load (1.45 kW), $1.1 \mathrm{~kW}$ (3/4 load), 0.75 kW (1/2 load) and $\mathbf{0 . 4}$ kW (1/4 load). At each load the engine parameters under consideration are: brake power, mass flow rates of air and fuel, volumetric efficiency, brake thermal efficiency and $b s f c$. The simulation model predicts residual gas fraction, $\mathrm{CO}$ concentration based on dry mole, NOx concentration and HC concentration. Table 2 shows the engine performance parameters at the loads under consideration.

Table 2 Original engine performance parameters at full load and part loads

\begin{tabular}{|l|l|l|l|l|}
\hline Engine parameter & Full load & $1.1 \mathrm{~kW}$ & $0.75 \mathrm{~kW}$ & $0.4 \mathrm{~kW}$ \\
\hline Brake thermal efficiency \% & 16.7 & 15.7 & 12.7 & 8.38 \\
\hline bsfc (kg/kW.h) & 0.486 & 0.518 & 0.638 & 0.97 \\
\hline Mass flow rate of air (kg/s) & $2.49 \mathrm{E}-3$ & $2.15 \mathrm{E}-3$ & $1.88 \mathrm{E}-3$ & $1.61 \mathrm{E}-3$ \\
\hline Mass flow rate of fuel $(\mathrm{kg} / \mathrm{s})$ & $1.96 \mathrm{E}-4$ & $1.58 \mathrm{E}-4$ & $1.33 \mathrm{E}-4$ & $1.08 \mathrm{E}-4$ \\
\hline Equivalence ratio & 1.19 & 1.11 & 1.07 & 1.01 \\
\hline Volumetric efficiency \% & 64.2 & 55.4 & 48.3 & 41.5 \\
\hline Residual gas fraction \% & 9.62 & 10.92 & 12.75 & 14.5 \\
\hline CO concentration \% & 4.86 & 2.95 & 1.88 & 0.61 \\
\hline $\mathrm{NO}_{\mathrm{x}}$ Concentration $(\mathrm{ppm})$ & 207 & 462 & 646 & 1035 \\
\hline $\mathrm{HC}$ concentration $(\mathrm{ppm})$ & 2633 & 2591 & 2749 & 2625 \\
\hline
\end{tabular}




\section{VVT ENGINE}

The experiments are carried out at full load and the same previous part loads. The same outputs are recorded for comparison. Two variation parameters are used for comparison, $\mathrm{V}_{1}$ and $\mathrm{V}_{2}$ as follows:

$$
V_{1} \%=\left(\left(\xi-\xi_{\text {orig }}\right) / \xi_{\text {org }}\right) \times 100
$$

Where: $V_{l}$ is the variation percentage, $\xi$ is the engine parameter under consideration and $\xi_{\text {org }}$ is the same parameter of the original engine under the same load. As the maximum value of each engine parameter does not occur at maximum brake thermal efficiency, another variation percentage $V_{2}$ illustrates the difference between the maximum engine parameter magnitude and its value at maximum brake thermal efficiency. This variation percentage is applied for the VVT engine only. It is defined as follows:

$$
V_{2} \%=\left(\left(\xi_{\eta_{b \text { max }}}-\xi_{\text {max }}\right) / \xi_{\text {max }}\right) \times 100
$$

Where: $\xi_{\text {max }}$ s the engine parameter under consideration and $\xi_{\eta_{b h \max }}$ is the same parameter at maximum brake thermal efficiency.

\subsection{Full Load}

Figures 8 to 16 illustrate the engine parameters variations with both auxiliary valve opening durations and closing angles. The auxiliary valve opening durations are listed on the top of each figure.

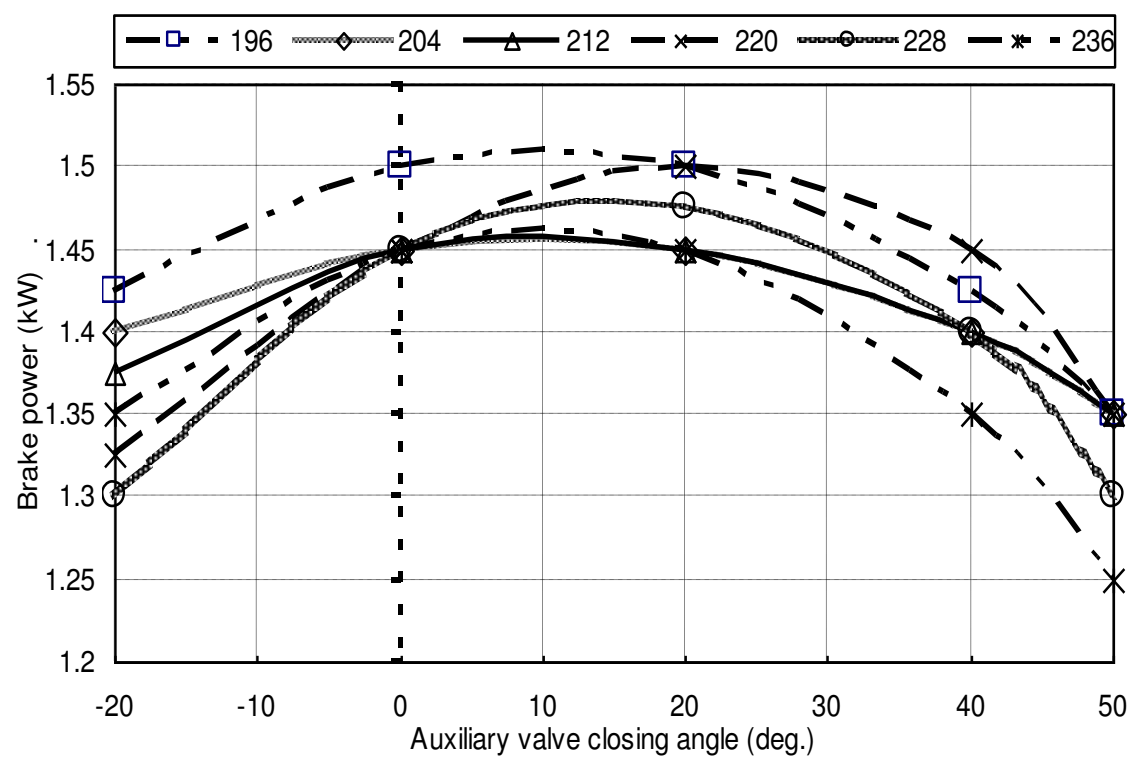

Fig. 8 Experimental variation of brake power with both auxiliary valve duration 


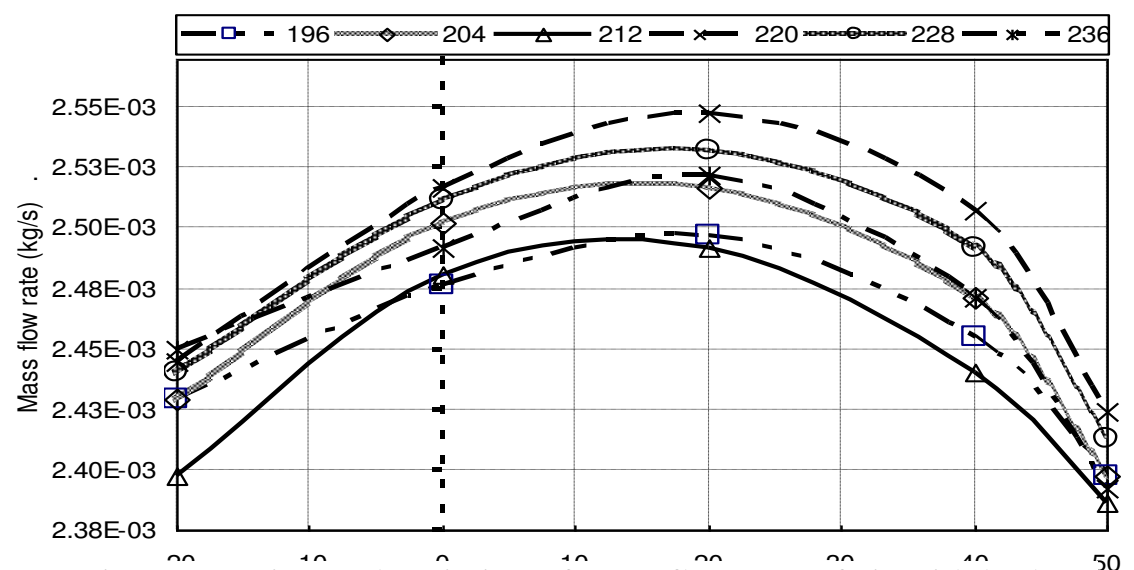

Fig. 9 Experimental variation of mass flow rate of air with both auxiliary valve duration and closing angle variations and closing angle variations

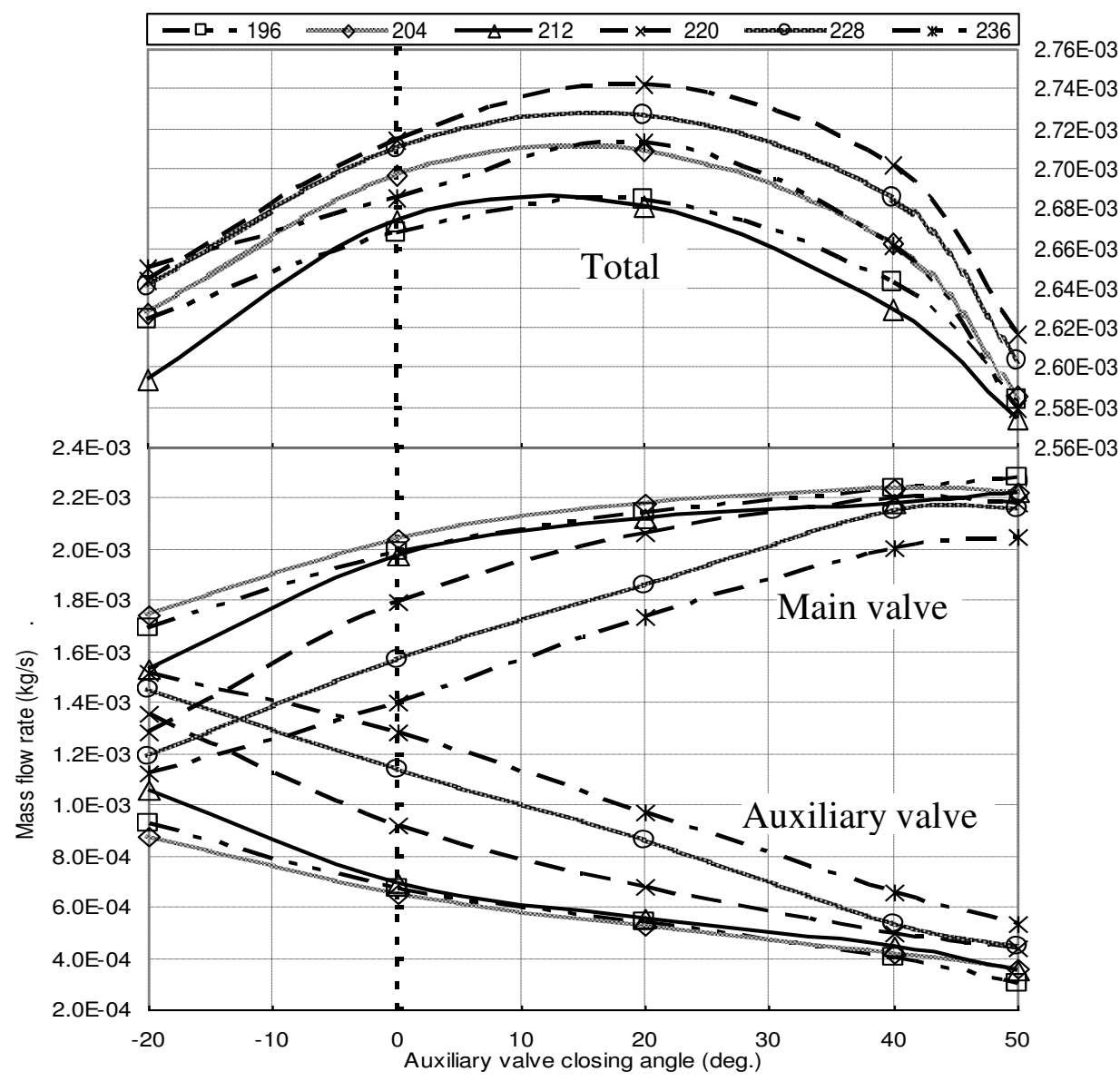

Fig. 10 Experimental variations of mass flow rates through both exhaust valves and the total mass with both auxiliary valve duration and closing angle variations 


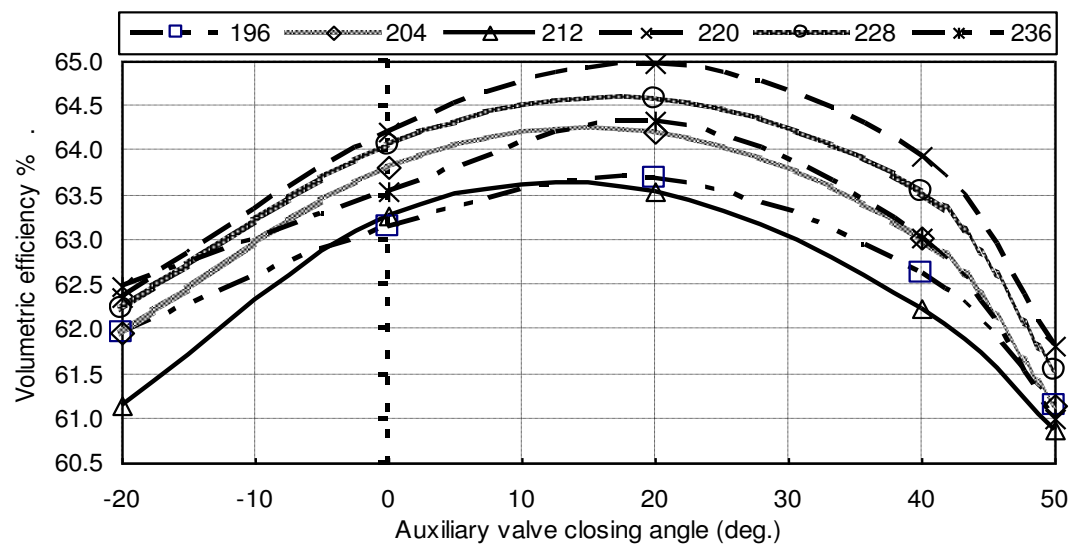

Fig. 11 Experimental variation of volumetric efficiency with both auxiliary valve duration and closing angle variations

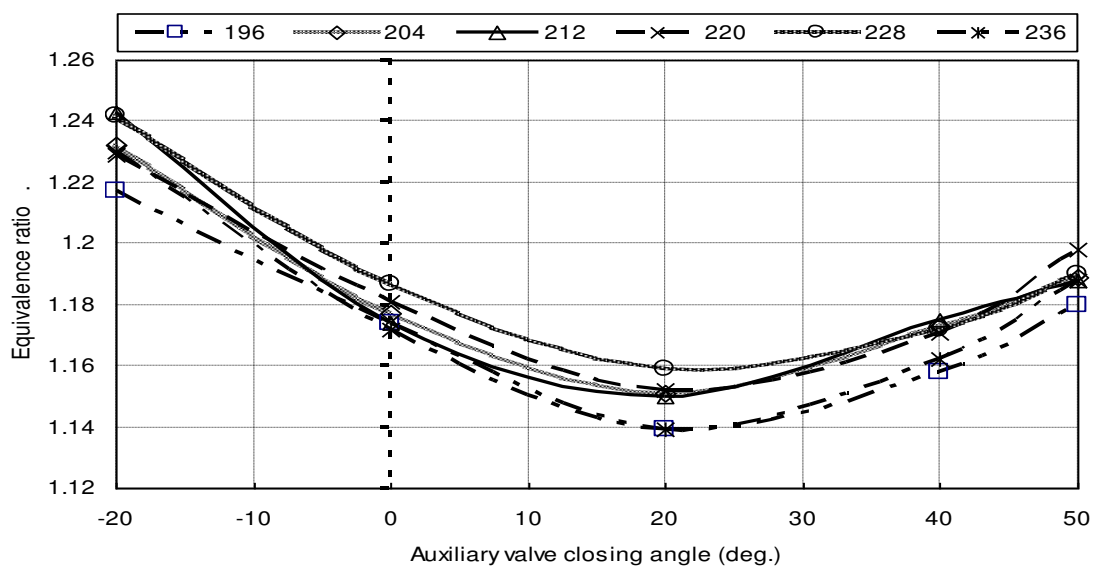

Fig. 12 Experimental variation of equivalence ratio with both auxiliary valve duration and closing angle variations

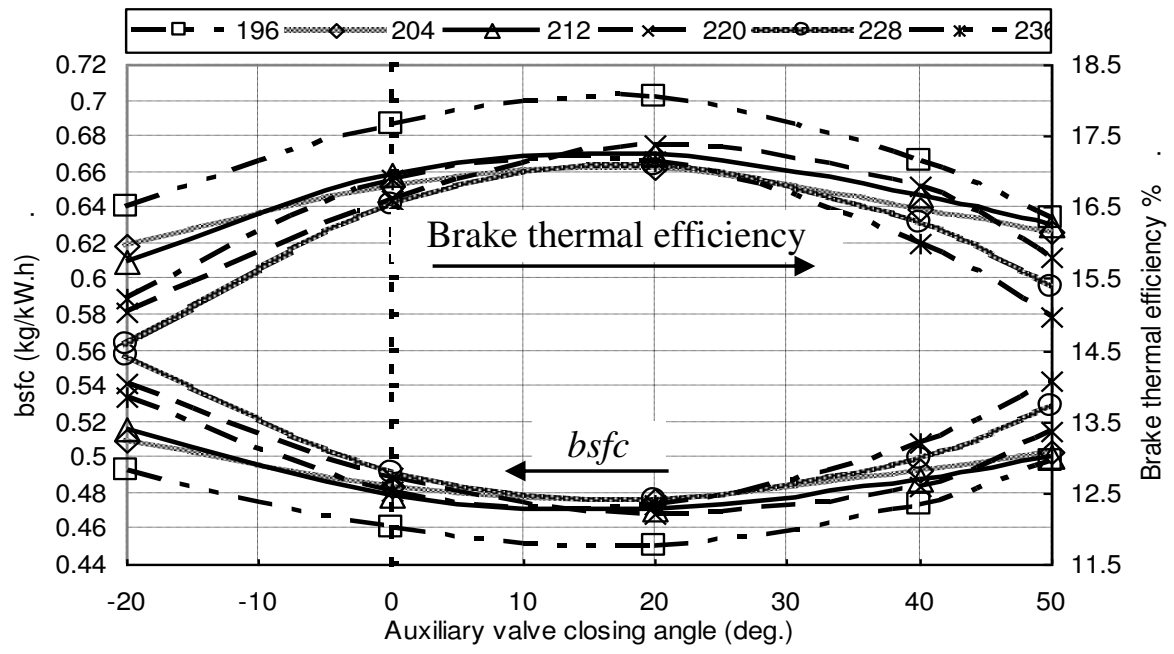

Fig. 13 Experimental variations of brake thermal efficiency and bsfc with both auxiliary valve duration and closing angle variations 


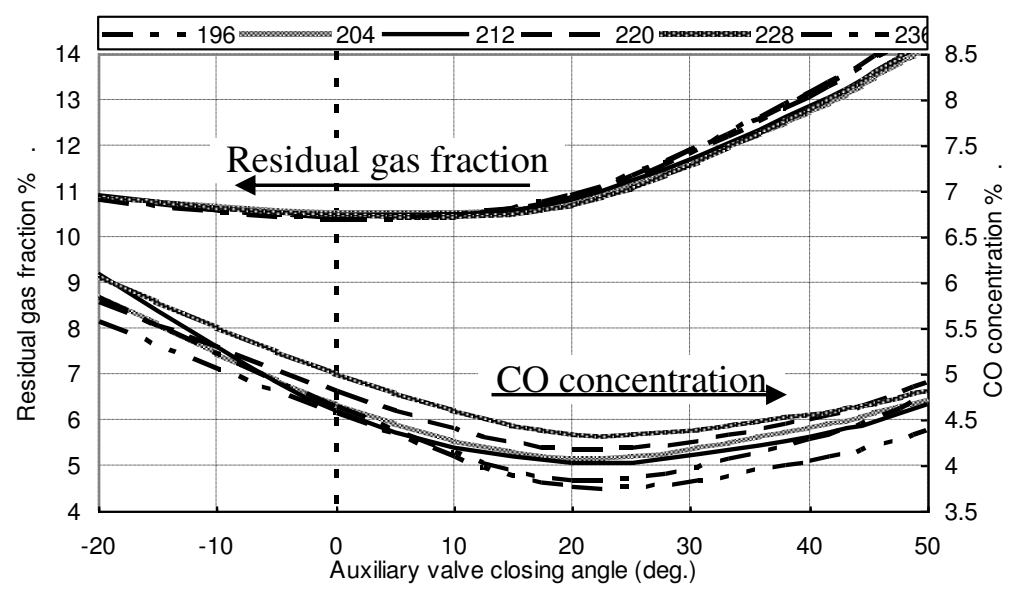

Fig. 14 Calculated variations of residual gas fraction and $\mathrm{CO}$ concentration with both auxiliary valve durations and closing angle variations

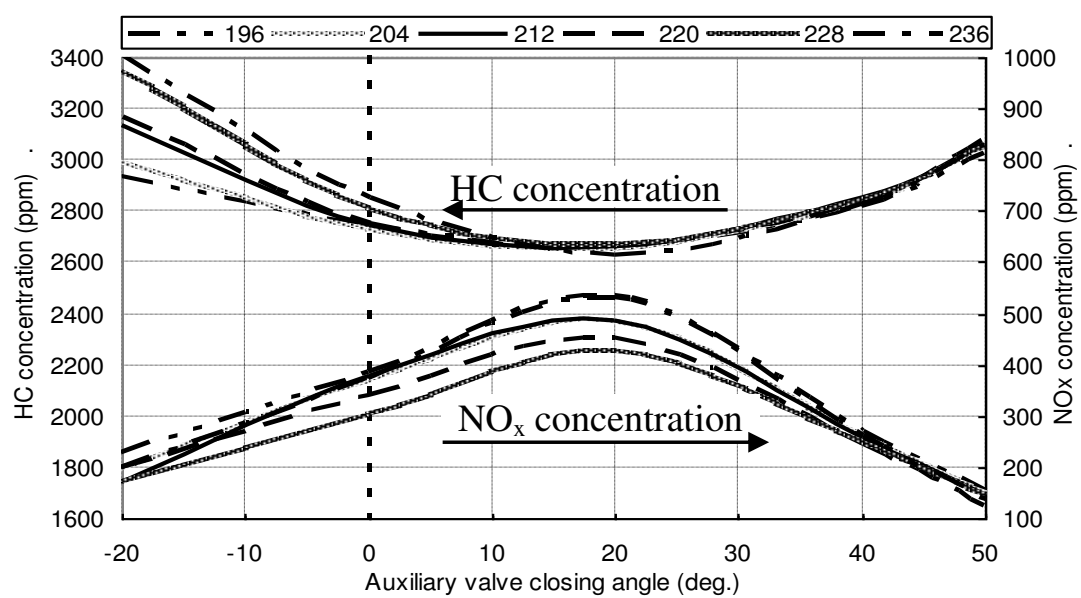

Fig. 15 Calculated variations of $\mathrm{NO}_{\mathrm{x}}$ and $\mathrm{HC}$ concentrations with both auxiliary valve duration and closing angle variations

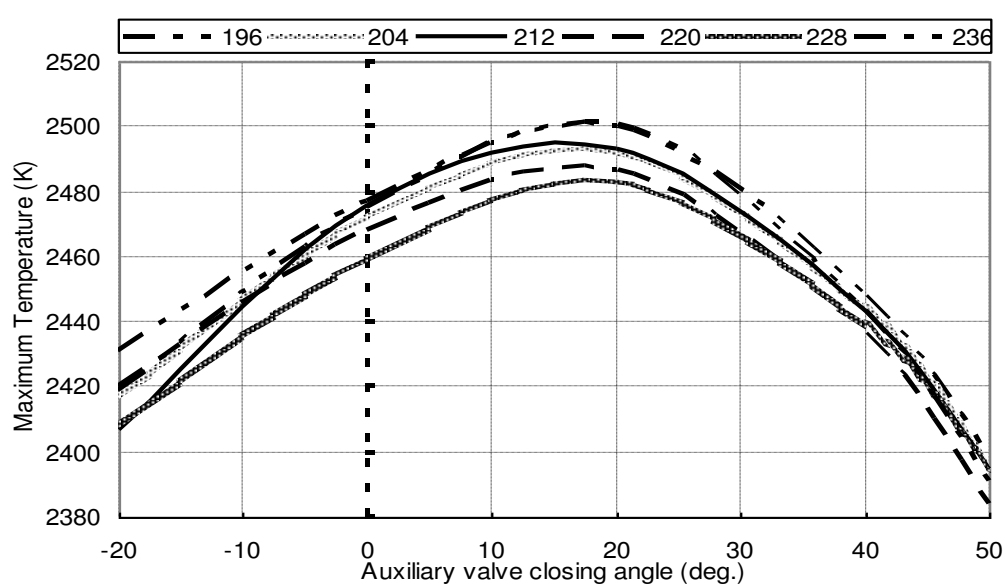

Fig. 16 Calculated variations of cylinder content maximum temperature with both auxiliary valve duration and closing angle variations 
As shown in Fig. 8, brake power increases in the range from $-20^{\circ}$ to $\left(10^{\circ}-20^{\circ}\right)$ as exhaust flow area during the valve overlap increases because of participation of auxiliary valve in it. After $\left(10^{\circ}-20^{\circ}\right)$, the power decreased because of the exhaust gas reverse flow through the auxiliary valve which decreases engine charging. Maximum brake power $=1.51 \mathrm{~kW}$ and occurs at $196^{\circ} \mathrm{CA}$ valve duration and $10^{\circ}$ valve closing angle.

Mass flow rate of air through intake valve increases in the range from $-20^{\circ}$ to $20^{\circ}$ and then decreases for the same previous reasons as shown in Fig. 9.

Exhaust mass flow rate through the auxiliary valve decreases while the valve closing angle moves from $-20^{\circ}$ to $50^{\circ}$ as shown in Fig. 10 as early opening of the valve enhances its participation in getting out the exhaust gases. For the same reason, higher valve durations have greater participation than lower valve durations.

The total mass flow rate through the exhaust valves in Fig. 10 which represents also the fresh charge has approximately the same trend of mass flow rate of air in Fig. 9 as the mass of fuel is relatively small compared with the mass of air.

Volumetric efficiency in Fig. 11 has also the same trend of mass flow rate of air in Fig. 9 for the same previous reason.

Equivalence ratio in Fig. 12 decreases in the range of (-20 to 20) due to the increment of the mass flow rate of air in this range. Then it increases in the rest range due to the decrement of the mass flow rate of air.

Brake thermal efficiency in Fig. 13 increases in the range from $-20^{\circ}$ to $17^{\circ}$ then decreases following approximately the charge mass flow rate in Fig. 10. Maximum brake thermal efficiency happens at valve duration of $196^{\circ} \mathrm{CA}$ and valve closing angle of $17^{\circ}$ with a value of $18.07 \%$ and variation percentage $\mathrm{V}_{1}=8.2 \%$. The corresponding $\mathrm{bsfc}=0.45 \mathrm{~kg} /(\mathrm{kW} . \mathrm{h})$ with variation percentage $\mathrm{V}_{1}=-7.4 \%$. At this condition $20.8 \%$ of the total mass of exhaust gets out through the auxiliary valve while the rest gets out through the main valve as shown in Fig. 10.

$\mathrm{CO}$ concentration in Fig. 14 decreases in the range of $-20^{\circ}$ to $20^{\circ}$ then increases following the trend of equivalence ratio in Figs. 12 as the increase of equivalence ratio leads to incomplete combustion and hence $\mathrm{CO}$ formation increases and vice versa. Residual gas fraction in Fig. 14 decreases in the range from $-20^{\circ}$ to $10^{\circ}$ because of overlap improvement and then increases quickly due to the reverse flow through the auxiliary valve.

$\mathrm{NO}_{\mathrm{x}}$ formation is an endothermal reaction depending on cylinder content temperature which increases with the increase of equivalence ratio till stoichiometric condition and then decrease at rich mixtures due to dissociation. Hence, $\mathrm{NO}_{\mathrm{x}}$ concentration trend in Fig. $\mathbf{1 5}$ follows the excess air factor which is the inverse of the equivalence ratio trend in Fig. 12.

$\mathrm{HC}$ concentration depends on the wall quench distance, craves volumes and oxidation rate. From the simulation model, it is found that, the change in wall quench distance is small as the variation in flame speed is small in the range of equivalence ratio that is achieved in these experiments and craves hydrocarbons variation is also small relative to the total amount of hydrocarbons. The important parameter is the oxidation rate which increases by cylinder content temperature increase.

Then HC in Fig. 15 has approximately a trend opposite to the cylinder content maximum temperature in Fig. 16. Maximum and minimum values of the parameters 
under consideration and their values at maximum brake thermal efficiency, $\mathrm{V}_{1}$ and $\mathrm{V}_{2}$ are illustrated in table 3.

From Figs. 8 to 16 and table 3 we can reach the following result; Valve duration of $196^{\circ} \mathrm{CA}$ and $17^{\circ}$ closing angle are the best conditions for running the engine at full load as it achieve the maximum brake thermal efficiency, approximately maximum brake power and mass flow rate of fresh charge. It also achieves approximately minimum fuel consumption, residual gas fraction, $\mathrm{CO}$ concentration and $\mathrm{HC}$ concentration, in spite of achieving nearly maximum $\mathrm{NO}_{\mathrm{x}}$ concentration.

Table 3 Magnitudes and variations of engine parameters

\begin{tabular}{|c|c|c|c|c|c|c|}
\hline \multirow{2}{*}{$\begin{array}{c}\text { Engine } \\
\text { parameter }\end{array}$} & \multirow{2}{*}{ description } & \multirow[b]{2}{*}{ magnitude } & \multicolumn{2}{|c|}{ Auxiliary valve } & \multirow[b]{2}{*}{$\mathrm{V}_{1} \%$} & \multirow[b]{2}{*}{$\mathrm{V}_{2} \%$} \\
\hline & & & duration & $\begin{array}{l}\text { closing } \\
\text { angle }\end{array}$ & & \\
\hline \multirow{2}{*}{$\begin{array}{l}\text { Brake power } \\
(\mathrm{kW})\end{array}$} & Maximum & 1.51 & 196 & 10 & 4.1 & \multirow{2}{*}{-0.66} \\
\hline & At $\eta_{b t h \max }$ & 1.5 & 196 & 17 & 3.75 & \\
\hline \multirow{2}{*}{$\begin{array}{l}\text { Mass flow rate } \\
\text { of air }(\mathrm{kg} / \mathrm{s})\end{array}$} & Maximum & $2.548 \mathrm{E}-3$ & 220 & 19 & 2.33 & \multirow[b]{2}{*}{1.96} \\
\hline & At $\eta_{b t h \max }$ & $2.498 \mathrm{E}-3$ & 196 & 17 & 0.3 & \\
\hline \multirow{2}{*}{$\begin{array}{l}\text { Mass flow rate } \\
\text { of fuel }(\mathrm{kg} / \mathrm{s})\end{array}$} & Minimum & $1.873 \mathrm{E}-4$ & 196 & 27 & -4.42 & \multirow[b]{2}{*}{0.37} \\
\hline & At $\eta_{b t h \max }$ & $1.880 \mathrm{E}-4$ & 196 & 19 & -4.08 & \\
\hline \multirow{2}{*}{$\begin{array}{l}\text { Mass flow rate } \\
\text { of fresh charge } \\
(\mathrm{kg} / \mathrm{s})\end{array}$} & Maximum & $2.742 \mathrm{E}-3$ & 220 & 19 & 2.1 & \multirow[b]{2}{*}{-2} \\
\hline & At $\eta_{b t h \max }$ & $2.685 \mathrm{E}-3$ & 196 & 17 & 0.05 & \\
\hline \multirow{2}{*}{$\begin{array}{l}\text { Equivalence } \\
\text { ratio }\end{array}$} & Minimum & 1.134 & 196 & 21 & -4.65 & \multirow[b]{2}{*}{0.26} \\
\hline & At $\eta_{b t h \text { max }}$ & 1.137 & 196 & 17 & -4.45 & \\
\hline \multirow{2}{*}{$\begin{array}{l}\text { Volumetric } \\
\text { efficiency \% }\end{array}$} & Maximum & 65 & 220 & 19 & 1.2 & \multirow[b]{2}{*}{-2} \\
\hline & At $\eta_{b t h \max }$ & 63.7 & 196 & 17 & -0.8 & \\
\hline \multirow{2}{*}{$\begin{array}{l}\text { Residual gas } \\
\text { fraction \% }\end{array}$} & Minimum & 9.1 & 228 & 11 & -5.2 & \multirow[b]{2}{*}{5.5} \\
\hline & At $\eta_{b t h \text { max }}$ & 9.6 & 196 & 17 & -0.2 & \\
\hline \multirow[t]{2}{*}{$\mathrm{CO} \%$} & Minimum & 3.74 & 196 & 22 & -23.25 & \multirow[b]{2}{*}{1.87} \\
\hline & At $\eta_{b t h \max }$ & 3.81 & 196 & 17 & -21.5 & \\
\hline \multirow[t]{2}{*}{$\mathrm{NO}_{\mathrm{x}}(\mathrm{ppm})$} & Maximum & 540 & 196 & 18.5 & 160 & \multirow[b]{2}{*}{-0.5} \\
\hline & At $\eta_{b t h \max }$ & 537 & 196 & 17 & 159 & \\
\hline \multirow[t]{2}{*}{$\mathrm{HC}(\mathrm{ppm})$} & Minimum & 2633 & 236 & 20 & 0.0 & \multirow[b]{2}{*}{0.76} \\
\hline & At $\eta_{b t h \text { max }}$ & 2653 & 196 & 17 & 0.75 & \\
\hline
\end{tabular}

\subsection{Part loads}

The same experiments and simulation are carried out at $1.1 \mathrm{~kW}, 0.75 \mathrm{~kW}$ and $0.4 \mathrm{~kW}$. It is found that valve duration of $196^{\circ} \mathrm{CA}$ is the best for all loads. The suitable closing angles are $23^{\circ}$ for $1.1 \mathrm{~kW}, 28^{\circ}$ for $0.75 \mathrm{~kW}$ and $24^{\circ}$ for $0.4 \mathrm{~kW}$ where the maximum 
brake thermal efficiencies occurred. Figures 17 to 24 show the different parameters variations for both original engine and VVT engine at $\xi_{\eta_{b b \max }}$ at different loads.

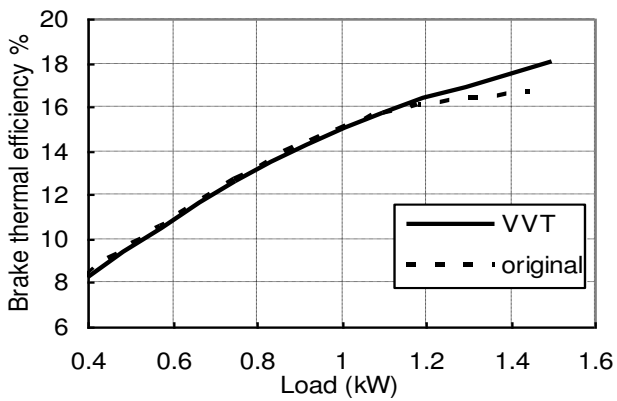

Fig.17 Variations of brake thermal efficiencies with load for original and VVT engines

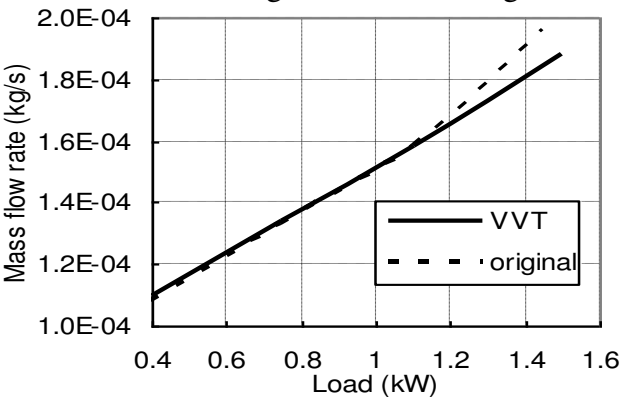

Fig.19 Variations of masses flow rate of fuel with load for original and VVT engines

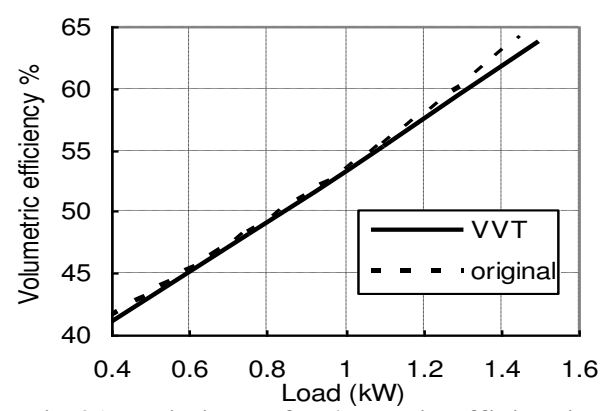

Fig.21 Variations of volumetric efficiencies with load for original and VVT engines

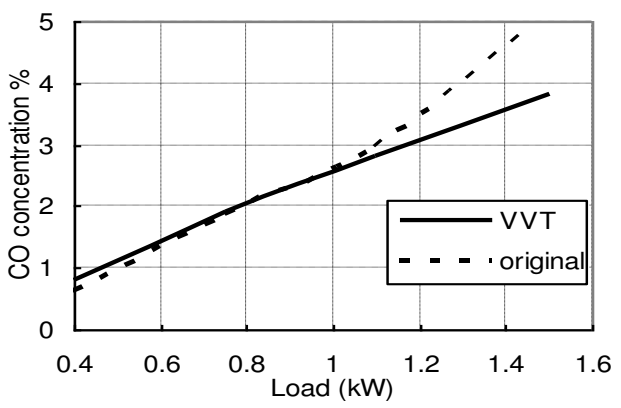

Fig.23 Variations of CO concentrations with load for original and VVT engines

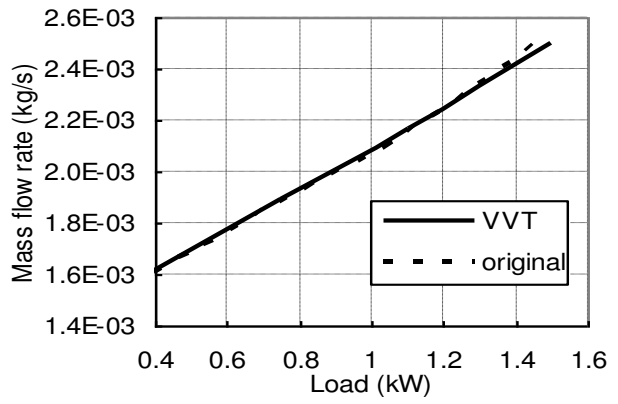

Fig.18 Variations of masses flow rate of air with load for original and VVT engines

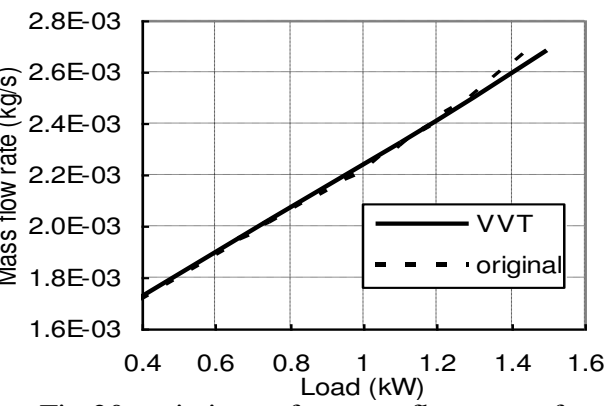

Fig.20 variations of masses flow rate of fresh charge with load for original

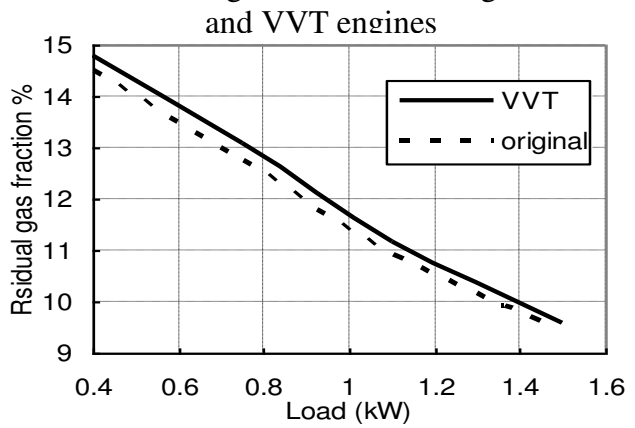

Fig.22 Variations of residual gas fractions with load for original and VVT engines

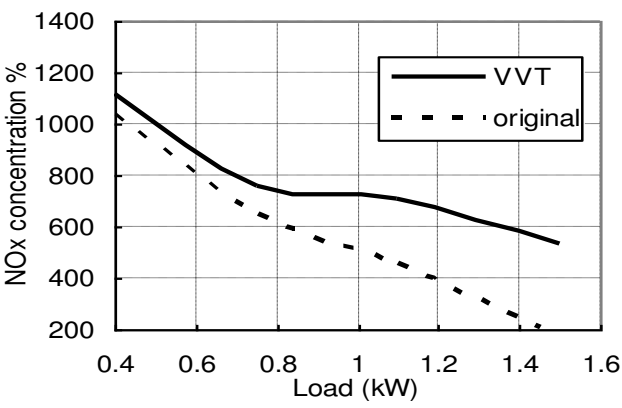

Fig.24variations of NOx concentrations with load for original and VVT engines 
Table 4 shows magnitude of the same previous parameters and their variation percentages at maximum brake thermal efficiency for the different mentioned loads.

Table 4 Engine parameters at the recommended valve timing

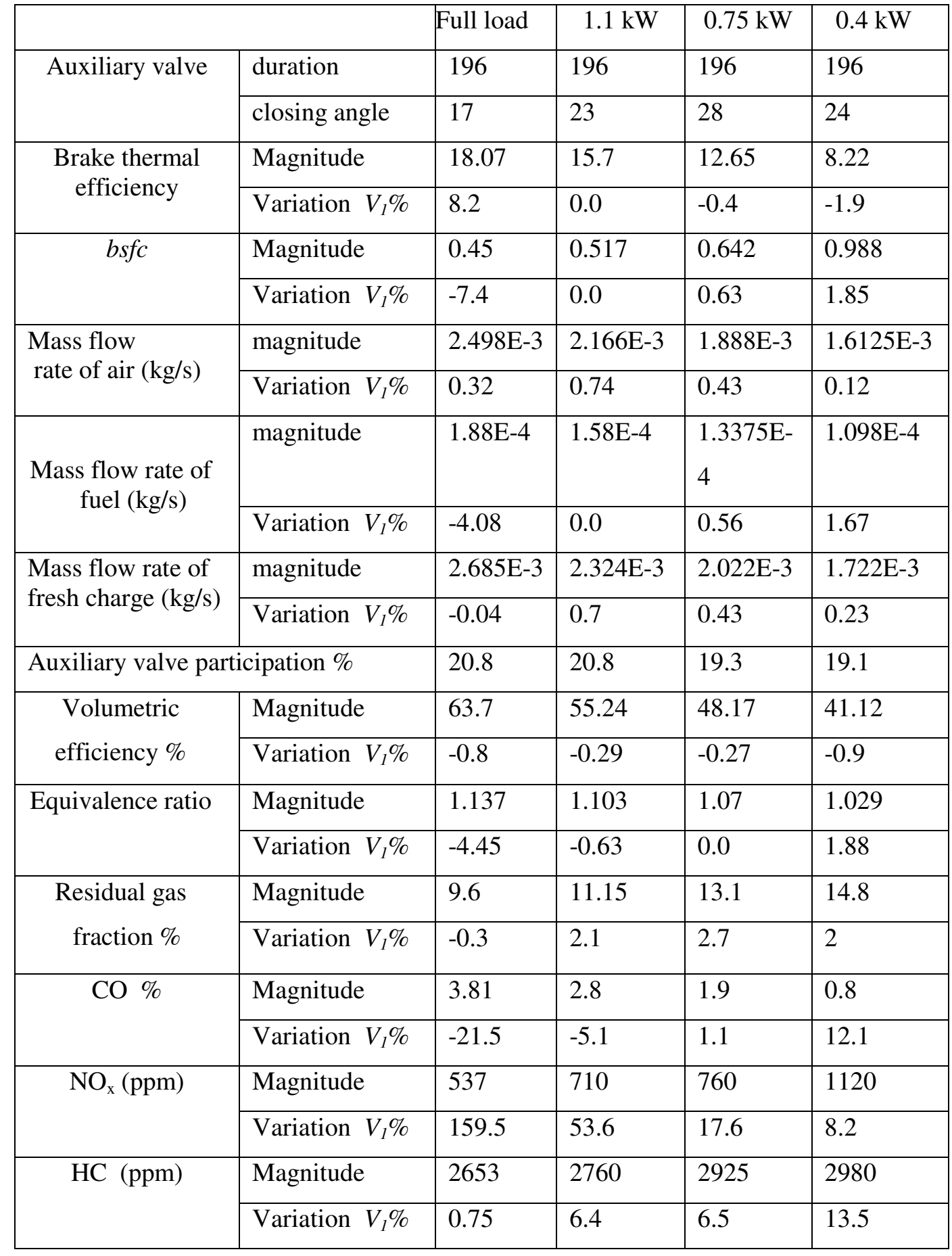


From Figs. 17 to $\mathbf{2 4}$ and table $\mathbf{4}$, it is obvious that:

1. Brake thermal efficiency is improved at full load by $8.2 \%$ but it decreased at part loads relative to the original engine. This means that the engine fuel consumption is increased at part loads.

2. Masses flow rates of air and fresh charge besides volumetric efficiency are mainly the same as that of the original engine at part loads.

3. Residual gas fraction increases while the load decreases and the VVT engine has a constant increase with a value of $0.3 \%$ over the whole range of load due to auxiliary valve participation in exhaust gas recirculation.

4. CO concentration decreased at small part loads and increased at moderate and full loads relative to the original engine following the same trend of the equivalences ratios of the VVT and original engines.

5. $\mathrm{NO}_{\mathrm{x}}$ decreased over the whole range of load relative to the original engine due to the increase of residual gas fraction.

6. HC increased over the whole range of load relative to the original engine because of the decrease in oxidation rate. The oxidation rate decreases due to the decrease in cylinder content temperature which occurs due to the increase of residual gas fraction.

\section{CONCLUSIONS}

The present study can be summarized in the following points:

1- VVT engine performance improved at full load relative to the original engine, but it worsened at part loads.

2- VVT engine with auxiliary exhaust valve having variable timing strategy is not recommended in engine application as it cannot improve the engine performance at part loads which is the real aim in spark ignition engines.

\section{REFERENCES}

1. Pierik, R. J. and Burkhard, J. F. "Design and Development of a Mechanical Variable Valve Actuation System" SAE Technical Paper Series 2000-01-1221March,2000.

2. Sellnau, M. and Rask, E. "Two-Step Variable Valve Actuation for Fuel Economy, Emissions, and Performance" SAE Technical Paper Series 2003-01-0029, March, 2003.

3. Jason, M. "Engine Modeling of an Internal Combustion Engine With Twin Independent Cam Phasing" Ph.D. Thesis, Ohio State University, 2007.

4. Heyood, J. B."Internal Combustion Engine Fundamentals", First Edition, McGRAW-HILL International Edition, 1988.

5. Campbell, A.S.” Thermodynamic Analysis of Combustion Engines “, John Willy \& sons Press, 1979.

6. Bishop, I. N."Effect of Design Variables on Friction and Economy", SAE Transaction, Vol.3 pp 334-358, 1965.

7. Annand, W. J. D."Heat Transfer in Cylinders of Reciprocating Internal Combustion Engines", Proc. Instn. Mech. Engre., 177, No.36 pp 973-990, 1963. 
8. Stone, R. "Introduction to Internal Combustion Engines" MACMILLAN PRESS LTD, 1999.

9. Annand, W. J. D., "Geometry of Spherical Flame Propagation in a Disc-Shaped Combustion Chamber", Journal of Mechanical Engineering Science, Vol., 12 No., 2, 1970.

10.Bishop, I. N."Effect of Design Variables on Friction and Economy", SAE Transaction, Vol.3 pp 334-358, 1965.

11.Abdel-rahim, Y. M."Analysis and Simulation of The IC Engines Otto Cycle Using The Second Law of Thermodynamics", Ph.D. Thesis, Kansas University, U.S.A, 1984.

12.Baghdadi, M. A. "Computer Simulation For Combustion And Exhaust Emissions In Spark Ignition Engine Fueled With Ethanol" Department of Mechanical Engineering, The Higher Center for Engineering Comprehensive Vocations, Yefren, Libya, 2001.

13.Bady, M. F. "Study of the Effects of Ethanol-Gasoline Blending Ratio on the exhaust Emissions and the Performance of a Spark Ignition Engines", M. Sc. Thesis, Assiut University, 2002.

14.Ferguson, C. R.’Internal Combustion Engines”, John Willy \& Sons, 1986.

15.Annand, W. J. D., "A new computational Model of Combustion in Spark Ignition Engines”, Proc. Instn. Mech. Engrs., Vol. 185, 1970.

16.Lavoie, G. A. and Blumberg, P. N. "Fundamental Model for Predicting Fuel Consumption, $\mathrm{NO}_{\mathrm{x}}$ and $\mathrm{HC}$ Emissions of Conventional S.I.E." Combustion Science and Technology, Vol. 21, 1980.

17.Annand, W. J. D. and Roa, G.E."Gas Flow in Internal Combustion Engine", Gtfoulis and Coldt Sparkford, Yeovil Somerset, 1974.

18.Benson, R. S. "An Approximate Solution for Non Steady Flow in Ducts with Friction “, Ent. J. Mech. Sci., Vol. 13 pp 819-824, 1971.

19.Azuma, T., Tokunaga, Y. and Yura, T."Characteristics of Exhaust Gas Pulsation of Constant Pressure Turbocharged Diesel Engines", Journal of Engineering and Power Oct., Vol. 102/827, 1980.

20.Kastner, L. J "An Investigation of the Air box Method of Measuring the Air Consumption of Internal Combustion Engine" Proc. Instn. Mech. Engrs., 1953.

21.Davies, P. O. and Dwger M. j." A Simple Theory for Pressure Pulses in Exhaust Systems "Proc. Instn. Mech. Engrs., Vol. 179, No. 10, pp 365-393, 1964-65.

22.Trengrouse, G. H., and Soliman, M. M."Effect of Sudden Change in Flow area on Pressure Wave of Finite Amplitude “, J. Mech. Eng. sci., Vol. 1948.

23.Agarwal, A., Filib, Z. S., Assanis, D. N. and Barker, D. M. "Assessment of a single and two zone turbulence formulations for quasi-dimensional modeling of spark-ignition engine combustion" Combustion Sci., and Tech., Vol., 136, 1998.

24.Sorde, J. R. "Modeling $\mathrm{NO}_{\mathrm{x}}$ Emissions from Spark-Ignition Engines" Proc., Instn. Mech. Engrs. Vol 214, 2000. 


\section{تأثير وجود صمام عادم ثانوي ذو توقيت متغير على أداء محرك البنزين}

تم استخدام طريقة جديدة لتغيير توقيت الصمامات تعتمد على اضافة صمام عادم ثانوي ينت التحكم فيه بميكانزم صمم خصيصا لذلك. والبحث الحالي يمنل دراسة عملية ونظرية لنطبيق هذه الطريقة مع تثنغيل

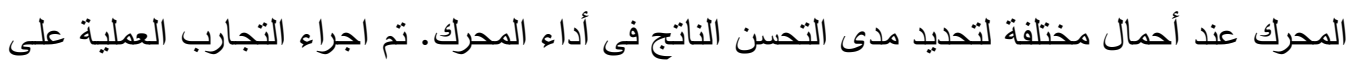

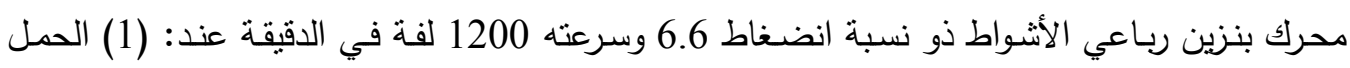

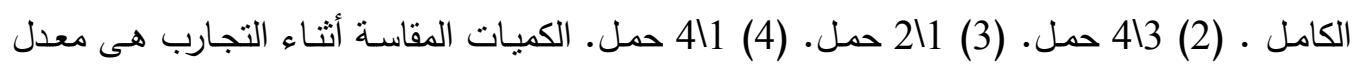

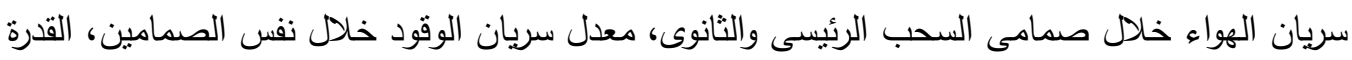

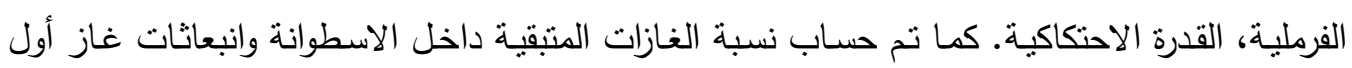

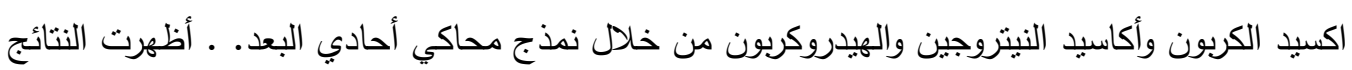
العملية والنظرية نسب التحسن في أداء الدحرك كالتالي:

1. الحمل الكامل: ذادت القدرة الفرملية بمقدار 4.1 \% كما ذادت الكفاءة الحرارية الفرملية بمقدار 8.2

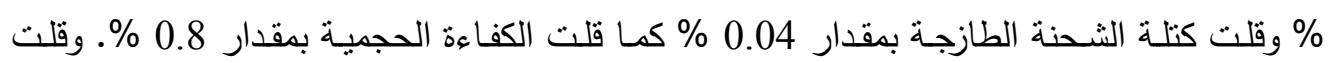

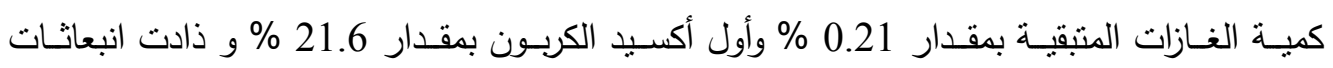
الهيدركوبون بمقدار 0.75\% و انبعاثات أكاسيد النيتوجين بمقدار 159.5 \%

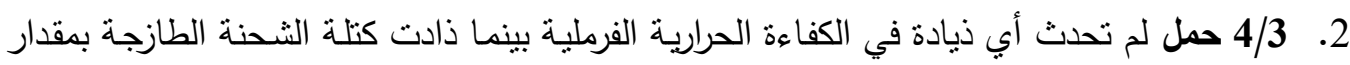

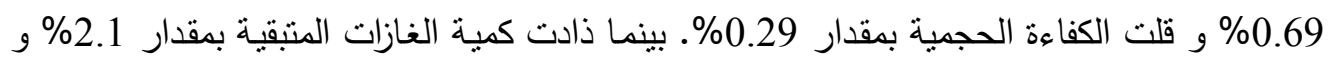

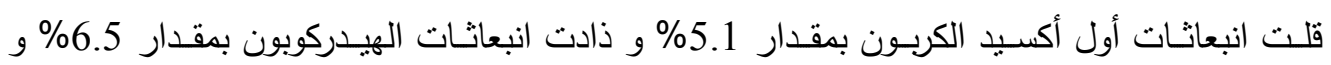
انبعاثات أكاسيد النيتوجين بمقدار 53.6\%

3. 2/1 حمـل: قلت الكفاءة الحراريـة الفرمليـة بمقدار 0.4 \% و و ذادت كتلـة الثـحنة الطازجـة بمقدار 0.43 \% و قلت الكفاءة الحجمية بمقدار 0.27 \% ـ و ذادت كمية الغازات المتنقية بمقدار 2.7 \% وأول أكسيد الكربون بمقدار 1.13 \% و ذادت انبعاثات الهيدركوبون بمقدار 6.5 \% و و انبعاثات أكاسيد

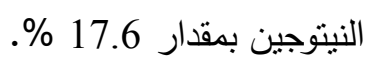

4. 4/1 حمل: قلت الكفاءة الحراريـة الفرملية بمقدار 1.9 \% كمـا قلت كتلة الثحنة الطازجة بمقدار

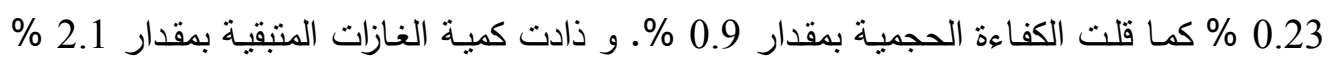
وأول أكسيد الكربـون بمقدار 31.1 \% و ذادت انبعانـات الهيدركوبون بمقدار 13.5 \% و و انبعاتات أكاسيد النيتوجين بمقدار 8.2\% و من ذلك يتضـح أن استخدام صمام عـادم ثانوي ذو نوقيت متغير يحسن أداء المحرك عند الحمل

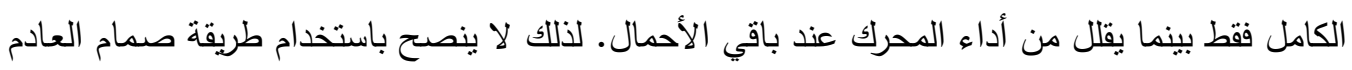
الثانوي ذو التوقيت المتغير في المحركات. 